\title{
ONLINE MCA (POK)
}

\author{
M. Ahamed Fysal ${ }^{1}$ and P.Sahaya Jenitha ${ }^{2}$ S.Ganapathy Subramanian ${ }^{3}$ \\ ${ }^{1}$ Department of Computer Application, Francis Xavier Engineering College \\ ${ }^{2}$ AP Department of Computer Application, Francis Xavier Engineering \\ College
}

${ }^{3}$ Department of Computer Application, Francis Xavier Engineering College

\begin{abstract}
The purpose of the project only for students knowledge. Students using the username \& password to login the website. These project have some new features. In this blog, Daily morning uploading top 5 technological news and entrepreneurs motivational videos, Technical videos, Technological Q\&A, Alumni projects with them the contacts, user can get marks and daily timetables.The newly joined students knows about MCA Rank holder, cultural, symposium and students can express their opinions and can say theirneeds.The students can knows about the In-campus drives and alumni placements. This document is meant for describing all the features and procedures that were followed while developing the system. This document specially mentions the details of the project how it was developed, the primary requirement, as well as various features and functionalities of the project and the procedures followed in achieving these objectives. The purpose of the project only for student knowledge. When students comes to website. They will learn one thing about technology. Its prominent intensity of this project. Students using the username \& password to login the website. These project have some new features. In this blog, Daily morning uploading 5 technological news and entrepreneurs motivational videos, technical videos, technologic $Q \& A$, Alumni project and download the project with zip file. The newly joined students knows about MCA cultural, symposium and students can express their opinions and can say their needs. The student can knows about the alumni placements details and contact with their social media.
\end{abstract}

\section{KEYWORDS}

\section{E-Learning System, Alumni Network Analysis, Campus Social Networking System}

\section{INTRODUCTION}

This project based on PHP Laravel. Its most scalability \& reduce code, Large community, rapidly create a web application and websites . Its have some additional features like videos, projects, alumni placements etc.The technological news is advantages of students and they improved their knowledge.This project is meant for describing all the features and procedures that were followed while developing the system. This document specially mentions the details of the project how it was developed, the primary requirement, as well as various features and functionalities of the project and the procedures followed in achieving these objectives. The purpose of the project only for student knowledge. When students comes to website. They will learn one thing about technology. Its prominent intensity of this project .Students using the username \& password to login the website. These project have some new features. In this blog, Daily morning uploading 5 technological news and entrepreneurs motivational videos, Technical videos, Technological Q\&A, Alumni project and download the project with zip file. The newly joined students knows 
about MCA cultural, symposium and students can express their opinions and can say their needs. The student can knows about the alumni placements details and contact with their social media.

\section{Research and Design of Web-based E-Learning System}

The paper combines the course with experience, creatively develops an E-Learning system based on web, and puts the basic theories of E-Learning and technical development into practice synthetically.

\section{Alumni Network Analysis}

Data on alumni has been used to estimate quality and impact of educational institutions. Tabular data about individuals' starting salaries, employment rate, and donation have been used to determine averages and comparisons.

\section{Design and Implementation of Campus Social Networking System}

New campus social networking system for users, which is tightly integrated with the reality environment of campus and users' real activity. It will not only achieve the basic communication function but also provide a unified platform for the teaching, researching, management and many other aspects of cultural life to teachers and students in campus. It is also an effective support for the information construction of university.

\section{Provision of the Social Media Service Framework based on the locality/sociality relations}

The paper introduces a methodology to provide the Social Media Service Framework (SMSF) in order to overcome the limitations of the traditional SNS services and to support the fundamental semantic web technologies including locality and sociality relationship management, active information and knowledge sharing schemes, digital community management, social user management based on ontology system.

The second section discuss about the literature review and continued by problem statements. The fourth section gives the experiments and results followed by the conclusion and future enhancement.

\section{Problem Statement}

\section{Architecture Diagram}

The Existing system only have some features like disciplinary section, timetable, department detail. Students can view their time tables. Students can't learn about technology. View their college cultural and facility. The student can't able to say their feedback. The Elearning students learn only for a suggested subjects. The youtube is a sentiment analysis is distract our mindset and divert your purpose. Students can only view their alumni placements and not able to contact with their alumni. They only get the news from the college or department. But the students aren't hear about tech news. In this proposed have more set of features like News, Motivational videos for motivate the students, students can say their needs, placement details and one main thing. Its only for MCA department. Students can view tech news, tech videos and gives their feedback. The students can view their alumni placements and directly contact with them. So they easy to get the job ideas. Students can view their alumni projects and download the zip file and 
project documentation and see the video of the project how is working. Students comments the videos what types of tech they needs. Daily morning Q/A for students quiz knowledge.

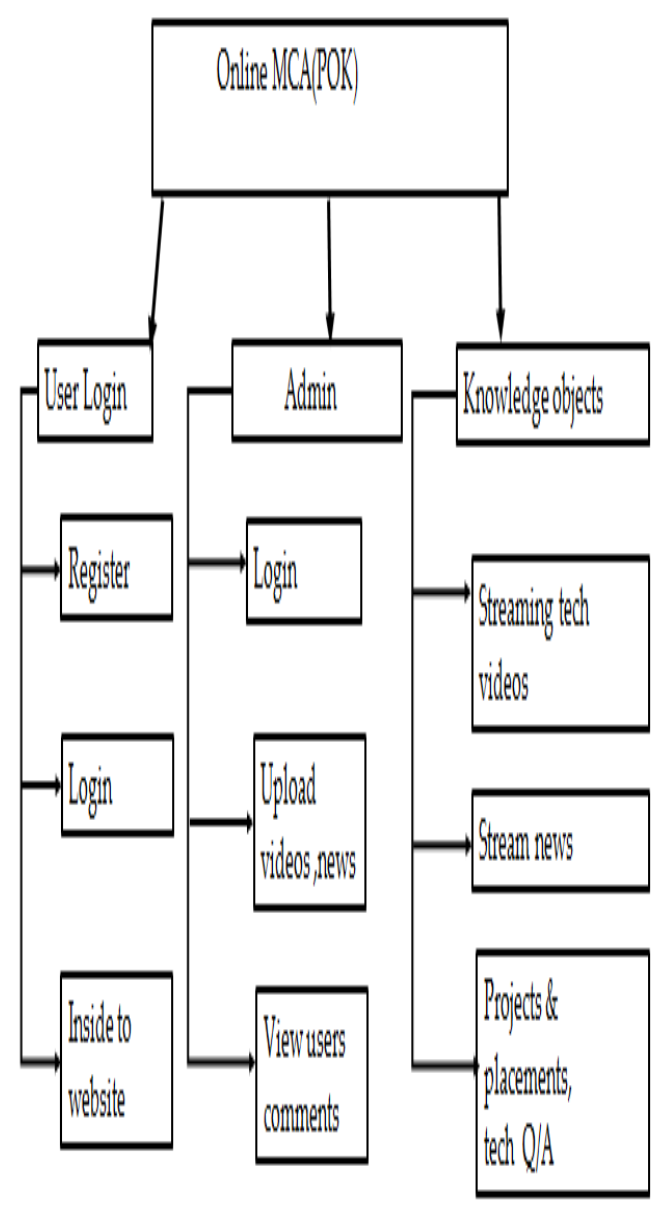

Figure :1Architecture Diagram

\section{EXPERIMENTS AND RESULTS}

\section{Modules}

The project "Online MCA(pok)" consists 5 modules for this knowledge system

1)User \& admin login

2)Tech News

3)Tech videos

4)Biopad

5)Alumni Projects

6)Alumni placements

7)Tech Questions

8)Chatbot

9)Student results 


\section{1) User \& admin Login}

This module was build to manage the user registration, user authentication, Admin interface, user login and successful logout from the web application. The user details are enrolled into the database with a registration form. After logout of the user, the web application redirects to the Home page.

\section{2) Tech News}

The student can read the daily tech news and comments, like or dislike.

The admin can read the user comments

\section{3) Tech videos}

The student can view the daily tech videos and comments, like or dislike.

\section{4) BioPOD}

The BioPOD used to translate the content in a native language which was preferred by the users. And admin can able to upload data in the voice mode.

\section{5) Alumni}

The student can see the alumni projects and download with zip file.then get project details with pdf.

\section{6) Alumni placements}

The student see the alumni placements and contact with them, Then students easily know MNC companies and college campus drive details.

\section{7) Tech Questions}

The students can attend the daily tech $\mathrm{Q} / \mathrm{A}$.

\section{8) Chatbot}

A chatbot is a computer program that's designed to simulate human conversation. Users just like they would converse with another person. Chatbots interpret the words given to them by a person and provide a pre-set answer"

\section{9) Student results}

The students can easily get the semester results and timetable even parents also get the result to this site.

\section{Data Connection}

Laravel makes connecting with databases and running queries extremely simple. The database configuration file is app/config/database.php. In this file you may define all of your database 
connections, as well as specify which connection should be used by default. Examples for all of the supported database systems are provided in this file.

Connections correspond to Sessions in SQL standard terminology. A client connects to the MySQL Server and stays connected until it does a disconnect.The MySQL Clients send connection requests to the MySQL Server. A connection request is simply a TCP-IP connect message sent to port 3306 on the server host machine.

\section{Output Screen}

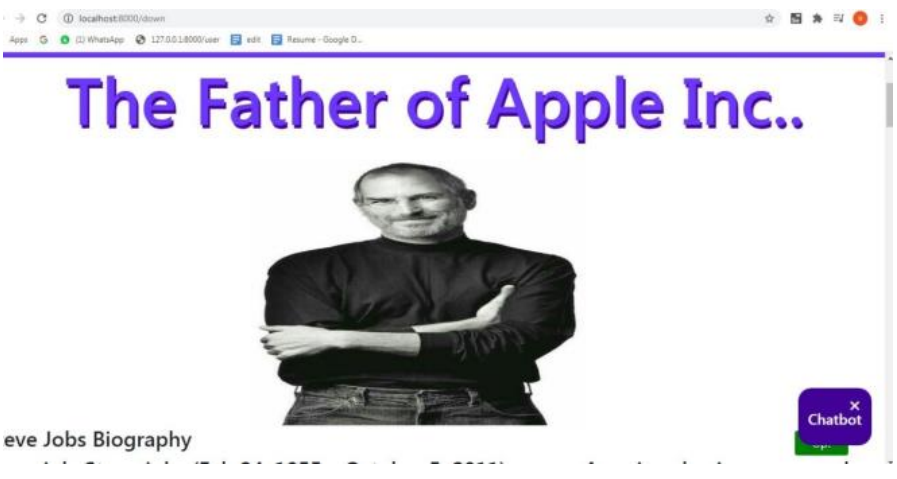

Figure :2 Home Page

Steve Jobs Biography

steve-jobsSteve Jobs (Feb 24, 1955 - October 5, 2011) was an American businessman and inventor who played a key role in the success of Apple computers and the development of revolutionary new technology such as the iPod, iPad and MacBook.

Early Life

Steve Jobs was born in San Francisco, 1955, to two university students Joanne Schieble and Syrian-born John Jandali. They were both unmarried at the time, and Steven was given up for adoption.

Steven was adopted by Paul and Clara Jobs, whom he always considered to be his real parents. Steven's father, Paul, encouraged him to experiment with electronics in their garage. This led to a lifelong interest in electronics and design.

Jobs attended a local school in California and later enrolled at Reed College, Portlan Oregon. His education was characterised by excellent test results and potential. But, Chatbot struggled with formal education and his teachers reported he was a handful to teac

Figure: 3 Biography 
- (1) Whotalapp (127.0018000/user 目 edit 目 Resume-Google D.

\section{MCA POK!}

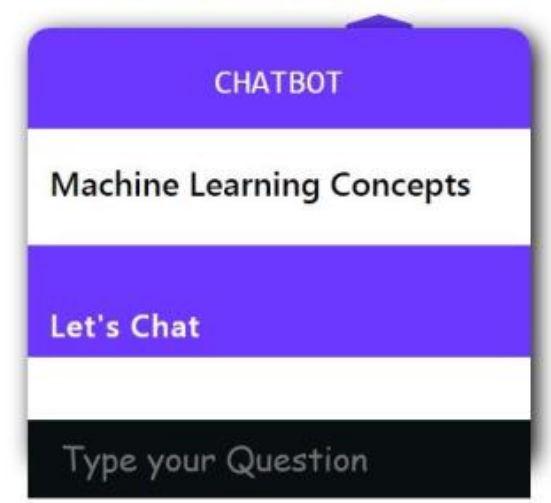

Figure :4 Chat Box
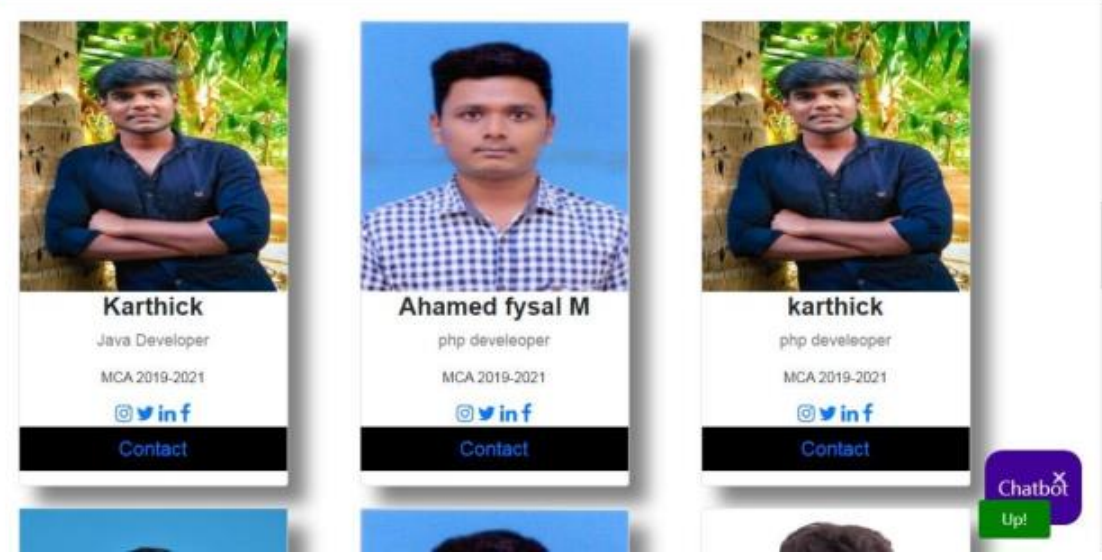

Figure: 5 Contact

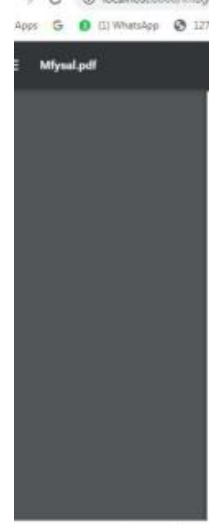

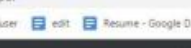

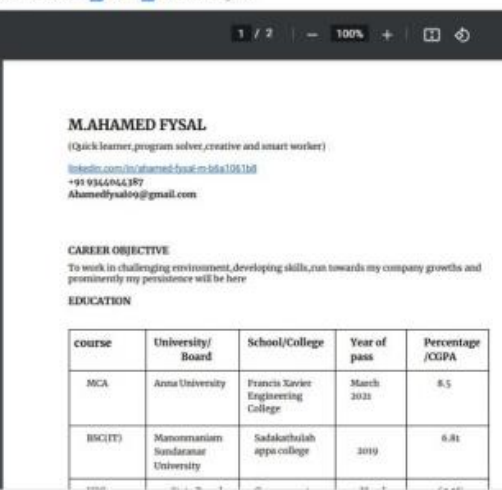

$\pm \mathbf{6}$

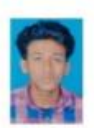

casernosesective

\begin{tabular}{|c|c|c|c|c|}
\hline course & $\begin{array}{l}\text { University/ } \\
\text { Baers }\end{array}$ & sctroal/collegere & $\begin{array}{l}\text { Year of } \\
\text { pass }\end{array}$ & $\begin{array}{l}\text { Percentatase } \\
\text { pocop }\end{array}$ \\
\hline $\mathrm{MaA}$ & 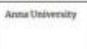 & 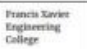 & $\begin{array}{l}\text { neod } \\
\text { noun }\end{array}$ & as \\
\hline moam & 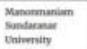 & 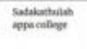 & saly & sat \\
\hline
\end{tabular}

Figure:6 Profile 


\section{MCA POK!}

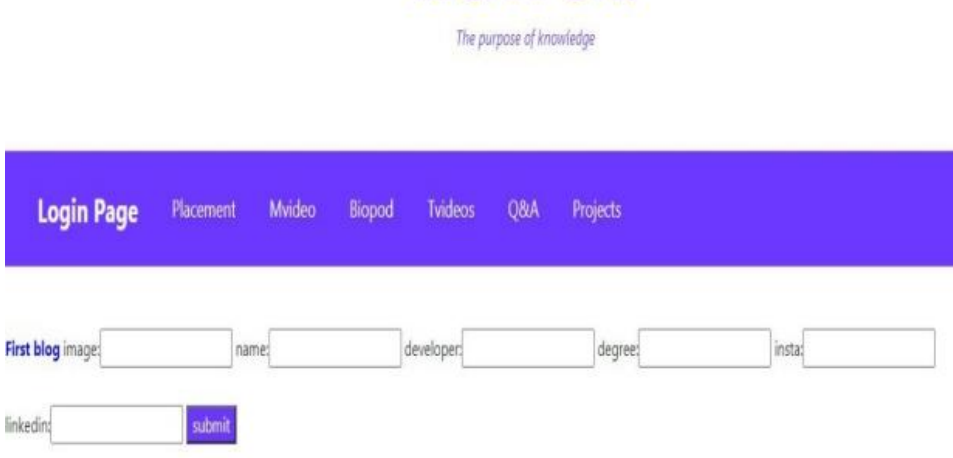

Figure :7Login Page
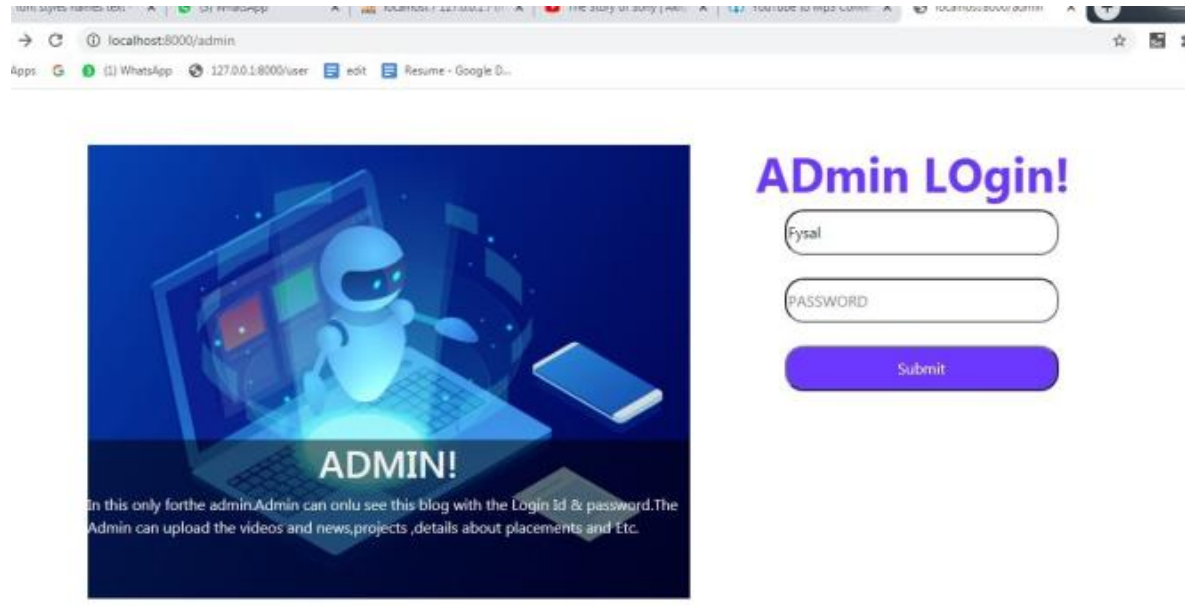

ADmin LOgin!

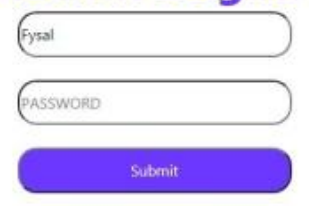

Figure :8 Admin Login

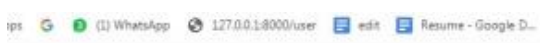

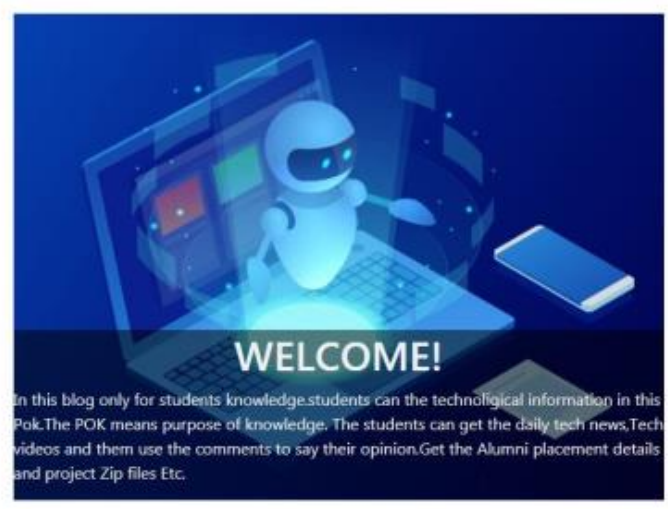

\section{StuDent LOgin!}

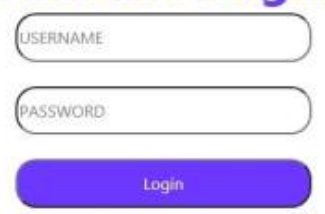

Sign up

Figure :9 Student Login 

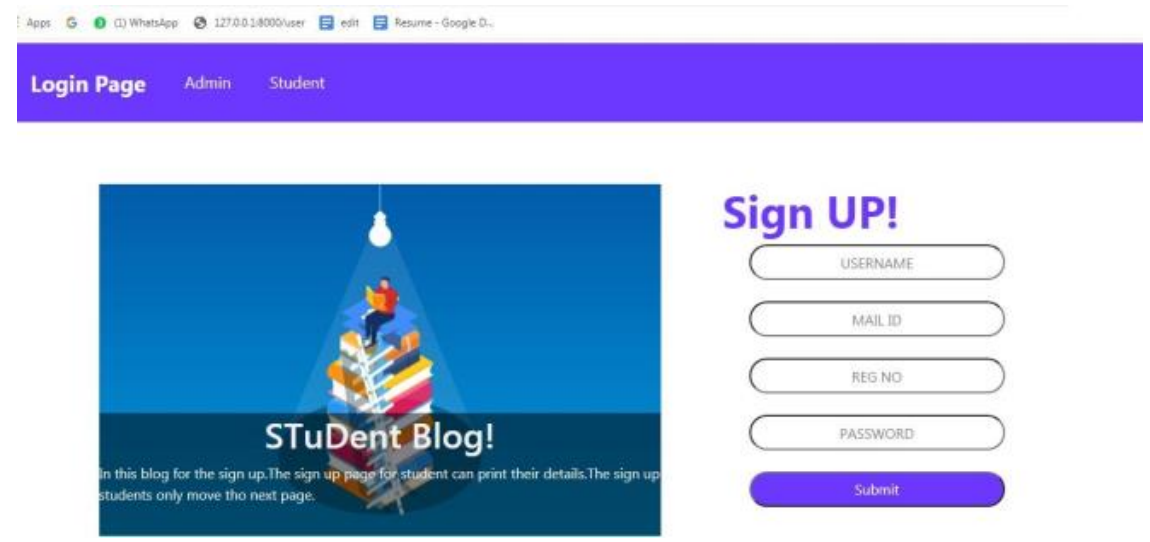

Figure :10 SignUp Page

\section{Performance Analysis}

The existing and proposed system are analysed. The problems can be easily rectified with this concept. Nearly $70 \%$ of the performance has been increased.

\section{CONCLUSION}

This was our project of System Design about "ONLINE MCA (POK)" developed as web application based on Php programming language. The Development of this system takes a lot of efforts from us. We think this system gave a lot of satisfaction to all of us. Though every task is never said to be perfect in this development field even more improvement may be possible in this application. We learned so many things and gained a lot of knowledge about development field.

\section{FUTURE ENHANCEMENT}

In future personalize experiences by providing recommendations based on individual preferences. Reduce screen interactions and time taken for checkout. Collect reviews and feedback. Provide users with the ease and convenience as against the time-consuming task of typing long feedbacks. In future, plan to implement the chats in our web application. The students directly chat with the professors. In future live video will be placed in this project.

\section{REFERENCES}

[1] Design and Implementation of College Student Information Management System Based on Web Services TANG Yu-fang'ZHANG Yong-sheng School of Information Science \& Engineering, Shandong Normal University, Jinan, 250014, China tangyufang2322@126.com; zys@ sanlian.com.cn.

[2] Social Media Enhanced Studying and Learning in Higher Education Kirsi Silius, Thumas Miilumäki, Jukka Huhtamäki, Teemo Tebest, Joonas Meriläinen, Seppo Pohjolainen Hypermedia Laboratory Tampere University of Technology Tampere, Finland kirsi.silius@tut.fi, thumas.miilumaki@tut.fi, jukka.huhtamaki@tut.fi, teemo.tebest@tut.fi, joonas.merilainen@tut.fi, seppo.pohjolainen@tut.fi

[3] Zhi-gang YUE, You-we JIN, “Thedevelopment and design of the student management system based on the network environment",2010 International Conference on Multimedia Communications,978-07695-4136-5/10 2010 IEEE.

[4] R. B. Guin, S. Chakrabarti, C. Tarafdar, and S. Mandal, "A smart architectural concept for the making of a university education system using cloud computing paradigm," in Proc. 2011 World Congress on Information and Communication Technologies, Mumbai, 2011, pp.48-52 
[5] College Student Management System Design Using Computer Aided System Liangqiu MENG Wuhan University of Technology; Wuhan, 430070 ,China; Guangxi University of Nationalities ;Nanning, 530006,China mengliangqiu2015@ sina.com

\section{AuTHORS}

M. Ahamed Fysal doing final year MCA in Francis Xavier Engineering College

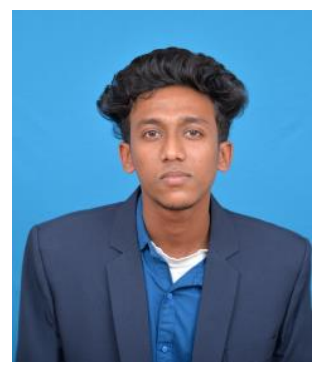

Mrs. S. Sahaya Jenitha working as

Assistant Professor in the

Department of Computer Applications,

Francis Xavier Engineering College.

Her area of interest is Wireless Sensor networks

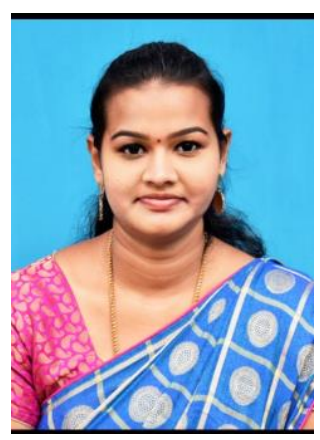

S.Ganapathy Subramanian doing first year MCA in Francis Xavier Engineering College

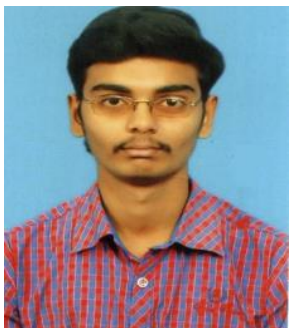

